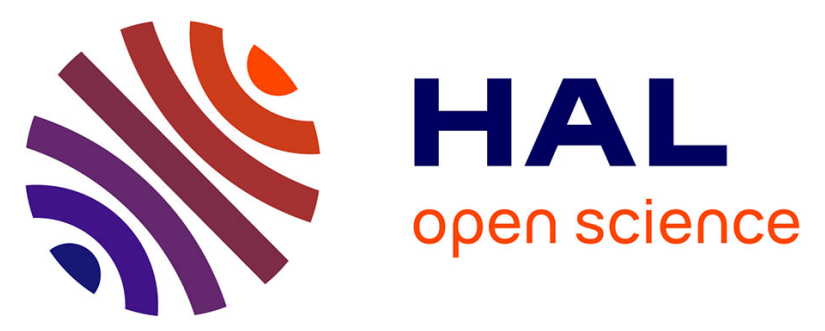

\title{
Measurement report: Spatial variations in snowpack ionic chemistry and water stable isotopes across Svalbard
}

\author{
Elena Barbaro, Krystyna Koziol, Mats P Björkman, Carmen P Vega, \\ Christian Zdanowicz, Jean-Charles Gallet, Daniel Kępski, Catherine Larose, \\ Bartlomiej Luks, Florian Tolle, et al.
}

\section{To cite this version:}

Elena Barbaro, Krystyna Koziol, Mats P Björkman, Carmen P Vega, Christian Zdanowicz, et al.. Measurement report: Spatial variations in snowpack ionic chemistry and water stable isotopes across Svalbard. Atmospheric Chemistry and Physics, 2021, 10.5194/acp-2020-740 . hal-03365920

\author{
HAL Id: hal-03365920 \\ https://hal.science/hal-03365920
}

Submitted on 5 Oct 2021

HAL is a multi-disciplinary open access archive for the deposit and dissemination of scientific research documents, whether they are published or not. The documents may come from teaching and research institutions in France or abroad, or from public or private research centers.
L'archive ouverte pluridisciplinaire HAL, est destinée au dépôt et à la diffusion de documents scientifiques de niveau recherche, publiés ou non, émanant des établissements d'enseignement et de recherche français ou étrangers, des laboratoires publics ou privés. 


\section{Measurement report: Spatial variations in snowpack ionic chemistry and water stable isotopes across Svalbard}

Elena Barbaro ${ }^{1,2}$, Krystyna Koziol ${ }^{3}$, Mats P. Björkman ${ }^{4}$, Carmen P. Vega ${ }^{5}$, Christian Zdanowicz ${ }^{6}$, Tonu Martma $^{7}$, Jean-Charles Gallet ${ }^{8}$, Daniel Kępski ${ }^{9}$, Catherine Larose ${ }^{10}$, Bartłomiej Luks ${ }^{9}$, Florian Tolle ${ }^{11}$, Thomas V. Schuler ${ }^{12,13}$, Aleksander Uszczyk ${ }^{14}$ and Andrea Spolaor ${ }^{1,2} *$

${ }^{1}$ Institute of Polar Sciences, ISP-CNR, Via Torino 155, 30170 Venice Mestre, Italy

${ }^{2}$ Department of Environmental Sciences, Informatics and Statistics, Ca' Foscari University of Venice, Via Torino 155, 30172, Venice, Italy.

${ }^{3}$ Department of Analytical Chemistry, Chemical Faculty, Gdansk University of Technology, G. Narutowicza 11/12, 80-233 Gdańsk, Poland.

${ }^{4}$ Department of Earth Sciences, University of Gothenburg, Box 460, SE-40530 Gothenburg, Sweden.

${ }^{5}$ Dirección Meteorológica de Chile, Dirección General de Aeronáutica Civil, Portales 3450, Santiago, Chile. Previously at: Department of Earth Sciences, Uppsala University, Villavägen 16, Uppsala, Sweden.

${ }^{6}$ Department of Earth Sciences, Uppsala University, Villavägen 16, SE-76236, Uppsala, Sweden.

${ }^{7}$ Department of Geology, Tallinn University of Technology, Ehitajate tee 5, 19086 Tallinn, Estonia ${ }^{8}$ Norwegian Polar Institute, Tromsø, No-9296, Norway

${ }^{9}$ Institute of Geophysics, Polish Academy of Sciences, Księcia Janusza 64, 01-452 Warsaw, Poland

${ }^{10}$ Environmental MicrobialGenomics, Laboratoire Ampère, CNRS, University of Lyon, France

${ }^{11}$ Université de Franche-Comté, Besancon, FEMTO-ST, UMR 6174 CNRS

${ }^{12}$ Departement of Geosciences, University of Oslo, Oslo, Norway

${ }^{13}$ Arctic Geophysics, University Center on Svalbard, UNIS, Longyearbyen, Svalbard, Norway

${ }^{14}$ University of Silesia in Katowice, Faculty of Natural Sciences, Będzińska 60, 41-200 Sosnowiec, Poland

\section{*Corresponding author}

Andrea Spolaor (andrea.spolaor@cnr.it)

\section{Keywords}

Snow, Svalbard, Arctic, inorganic ions, water isotopes 


\section{Abstract}

The Svalbard archipelago, between $74^{\circ}$ and $81^{\circ} \mathrm{N}$, is $\sim 60 \%$ covered by glaciers and located at the Arctic sea ice edge. The region experiences rapid variations in atmospheric flow during the snow season (from late September to May) and can be affected by air advected both from lower and higher latitudes, which likely impact the chemical composition of snowfall. While long-term changes in Svalbard snow chemistry have been documented in ice cores drilled from two high-elevation glaciers, the spatial variability of the snowpack composition across Svalbard is comparatively poorly understood. Here, we report the results of the most comprehensive seasonal snow chemistry survey to date, carried out in April 2016 across 22 sites on 7 glaciers across the archipelago. At each glacier, three snow pits were sampled along altitudinal profiles and the collected samples were analysed for major ions $\left(\mathrm{Ca}^{2+}, \mathrm{K}^{+}, \mathrm{Na}^{+}, \mathrm{Mg}^{2+}\right.$, $\mathrm{NH}_{4}{ }^{+}, \mathrm{SO}_{4}{ }^{2-}, \mathrm{Br}^{-}, \mathrm{Cl}^{-}$and $\left.\mathrm{NO}_{3}{ }^{-}\right)$and stable water isotopes $\left(\delta^{18} \mathrm{O}, \delta^{2} \mathrm{H}\right)$. The main aims were to investigate the natural and anthropogenic processes influencing the snowpack and to better understand the influence of atmospheric aerosol transport and deposition patterns on the snow chemical composition. The snow deposited in the southern region of Svalbard was characterized by the highest total ionic loads, mainly attributed to sea salt particles. Both $\mathrm{NO}_{3}{ }^{-}$and $\mathrm{NH}_{4}{ }^{+}$in the seasonal snowpack reflected secondary aerosol formation and post-depositional changes, resulting in very different spatial deposition patterns: $\mathrm{NO}_{3}{ }^{-}$had its highest loading in northwestern Spitsbergen, and $\mathrm{NH}_{4}{ }^{+}$in the southwest. The $\mathrm{Br}^{-}$enrichment in snow was highest in northeastern glacier sites closest to areas of extensive sea ice coverage. Spatial correlation patterns between $\mathrm{Na}^{+}$and $\delta^{18} \mathrm{O}$ suggest that the influence of long-range transport of aerosols on snow chemistry is proportionally greater above $600-700 \mathrm{~m}$ a.s.1.

\section{Introduction}

Svalbard is a region of the Arctic experiencing rapid climate change, with a mean warming rate of +1.35 $\mathrm{K}$ per decade, much faster than the global average (Isaksen et al., 2016; Maturilli et al., 2013; Nordli et al., 2014). This archipelago is located at the southern edge of the perennial Arctic sea ice, in the North Atlantic Ocean, and is characterized by a maritime climate with large, rapid temperature variations during winter (Brage et al., 2014). South-westerly inflow of mild oceanic air, associated with a lowpressure system east of Iceland, often brings relatively warm and moist air in winter months, while Arctic air intrusions from the north-east, driven by a high-pressure system over Greenland, result in much colder temperatures (Rinke et al., 2017). In addition to these synoptic fluctuations, intense autumn or winter cyclonic storms associated with anomalous warming events sometimes occur, transporting both heat and moisture from lower latitudes to Svalbard (Rinke et al., 2017).

The aforementioned meteorological conditions also favor long-range transport of aerosols to the archipelago, including pollutants from continental sources. Depending on the predominant air flow pattern at the time of snowfall, the archipelago may experience regionally different amounts of both snow accumulation (Eneroth et al., 2003; Forland et al., 2011) and chemical loads, the latter reflecting 
contrasting mixtures of aerosol, varying by source area (Aas et al., 2016; Forsström et al., 2009; Möller and Kohler, 2018). These regional differences are also associated with contrasts in sea ice cover. While all Svalbard coasts are usually ice-free in summer, sea ice can form and cover large parts of the ocean surface in the eastern and northern parts of the archipelago, while the southern and western parts often remain ice-free (Dahlke et al., 2020), and therefore tend to experience greater snowfall owing to the proximity of open water. In addition, the West Spitsbergen Current, a branch of the Atlantic Meridional Overturning Circulation (AMOC) that flows to the west of the archipelago, causes markedly different regional climatic conditions between its eastern and western parts (van Pelt et al., 2019): the west exhibits higher temperatures and precipitation, while the east is less humid and cooler, and has also experienced a stronger warming trend since 1957.

The seasonal snowpack contains a complex mixture of impurities that are either scavenged from the atmosphere during snowfall or directly received through dry deposition (Kuhn, 2001). On land, the majority of impurities found in seasonal snow are usually eluted during summer melting, influencing terrestrial and aquatic systems (Björkman et al., 2014; Brimblecombe et al., 1987). However, in the accumulation area of Arctic glaciers and ice caps, impurities can be retained within or below the seasonal snow layer (Björkman et al., 2014; Pohjola et al., 2002; Vega et al., 2015b). For this reason, chemical impurities such as major ions $\left(\mathrm{Ca}^{2+}, \mathrm{K}^{+}, \mathrm{Na}^{2+}, \mathrm{Mg}^{2+}, \mathrm{NH}_{4}{ }^{+}, \mathrm{SO}^{2-}, \mathrm{Br}^{-}, \mathrm{Cl}^{-}\right.$and $\left.\mathrm{NO}_{3}{ }^{-}\right)$in ice cores have been widely used to study past trends of atmospheric and climatic conditions (Barbante et al., 2017; Isaksson et al., 2003; Thompson et al., 2002; Wolff et al., 2010). Previous studies in Svalbard (GotoAzuma et al., 1994; Nawrot et al., 2016; Semb et al., 1984; Winther et al., 2003) have shown that the chemistry of the seasonal snowpack is dominated by sea salt ions (Hodgkins and Tranter, 2017). However, the region is also a sink for atmospheric contaminants brought in by long-range transport (Vecchiato et al., 2018). Investigations of precipitation and snow cover chemistry have predominantly focused on the central and western parts of the archipelago (Kühnel et al., 2011; Nawrot et al., 2016; Vega et al., 2015a; Virkkunen et al., 2007), due to the accessibility of research facilities in these sectors.

In the present study, the concentration, mass loading, spatial and altitudinal distribution of major ion species $\left(\mathrm{Ca}^{2+}, \mathrm{K}^{+}, \mathrm{Na}^{2+}, \mathrm{Mg}^{2+}, \mathrm{NH}_{4}{ }^{+}, \mathrm{SO}_{4}{ }^{2-}, \mathrm{Br}^{-}, \mathrm{Cl}^{-}\right.$and $\left.\mathrm{NO}_{3}{ }^{-}\right)$in snow, together with its stable oxygen and hydrogen isotope composition $\left(\delta^{18} \mathrm{O}\right.$ and $\left.\delta^{2} \mathrm{H}\right)$, were evaluated in the late winter snowpack at 22 glacier sites across Svalbard. This study was part of the larger Community Coordinated Snow Study in Svalbard (C2S3) project and the most comprehensive survey of seasonal snow chemistry in Svalbard to date. The snowpack survey, which was carried out by coordinated teams using a standardized sampling protocol (Gallet et al., 2018) aimed to map and characterize regional differences in the chemical composition and impurity load of the winter snow pack, and interpret the observed differences in relation to meteorological and other environmental factors. In this way, we aim to identify the conditions 
controlling the chemistry of Svalbard snow that are susceptible to be influenced by future climate warming across the region.

\section{Methods}

\subsection{Sampling location and strategy}

During April 2016, the seasonal snowpack was sampled at 22 sites on seven glaciers across Svalbard: Austfonna (AF) on Nordaustlandet, Lomonosovfonna (LF) on central Spitsbergen, Hansbreen (HB) and Werenskiöldbreen (WB) in the Hornsund area of southern Spitsbergen, and Austre Lovénbreen (ALB), Kongsvegen (KVG) and Holtedahlfonna (HDF) in the vicinity of Ny-Ålesund on northwestern Spitsbergen (Table 1 and Figure 1). The glaciers are of different sizes and hypsometries. Each glacier was sampled in the ablation zone, close to the equilibrium line altitude (ELA), and in the accumulation zone (Table 1). The ELA is the elevation at which the surface mass balance is zero, i.e., where the accumulation of snow is exactly balanced by ablation over a period of a year (Cogley et al., 2011). Although the exact elevation range of these zones differ for each glacier, they share enough glaciological similarities to support inter-site comparisons. Snowpit sampling was performed using a standardized common protocol (Gallet et al., 2018) with pre-cleaned equipment (i.e., tubes, plastic scrapers and plastic shovels cleaned with ultrapure water) and protective clothing (powder-free plastic gloves, clean suits and face masks). Samples for ionic chemistry were taken in each discrete snow pit layer, according to the visible stratigraphy, and directly into pre-cleaned, $50 \mathrm{~mL}$ polypropylene "Falcon" centrifuge tubes. Samples for the isotopic composition of water were collected at a $5-\mathrm{cm}$ resolution for sites in the NyÅlesund area and at a $10-\mathrm{cm}$ or stratigraphic layer resolution for other sites. All sampling was conducted in a safe distance and upwind from potential local pollution sources, such as the snowmobiles used as transport by the sampling team.

\subsection{Major ion analyses}

Samples from glaciers in the Hornsund region (HB, WB) were analysed at the Polish Polar Station Hornsund (Institute of Geophysics, Polish Academy of Sciences), while samples from glaciers near NyÅlesund (KVG, ALB, HDF) were shipped frozen to the Institute of Polar Sciences (ISP-CNR) in Venice (Italy). Snow sampled in central Spitsbergen (AF, LF) was shipped frozen to the Department of Earth Sciences at Uppsala University (Sweden). Due to a temporary equipment malfunction in Uppsala, only cations could be analysed there, and the refrozen samples were forwarded to ISP-CNR for anion analysis. All samples and standards were handled and prepared under clean room conditions, wearing powder-free gloves. In all labs except at the Polish Polar Station Hornsund, laminar flow hoods (class 100) were used. Samples were melted immediately before analysis.

\subsubsection{Hornsund}


Samples were filtered through $0.45 \mu \mathrm{m}$ mixed cellulose esters membranes (Merck Millipore S-pak ${ }^{\circledR}$ ) prior to analysis. Ion concentrations were determined on a Metrohm 761 Compact IC ion chromatograph equipped with an autosampler (Metrohm, Herisau, Switzerland), with isocratic flow, and chemical suppression for anions (column Metrosep A Supp S + Metrosep A Supp 4/5 Guard 4.0, eluent: $\mathrm{NaHCO}_{3}$ $1.0 \mathrm{mmol} \mathrm{L}{ }^{-1}+\mathrm{Na}_{2} \mathrm{CO}_{3} 3.2 \mathrm{mmol} \mathrm{L}^{-1}$ ). Cations were determined without suppression (column Metrosep $\mathrm{C} 4$ + Metrosep C4 Guard; eluent: $\mathrm{HNO}_{3} 1.7$ mmol L${ }^{-1}+2,6$-pyridinecarboxylic acid [dipicolinic acid, or DPA] $0.7 \mathrm{mmol} \mathrm{L}^{-1}$ ). Cation samples were acidified with $2 \mu \mathrm{L}$ of $2 \mathrm{mM} \mathrm{HNO}_{3}$ per $10 \mathrm{~mL}$ sample prior to analysis, as recommended for this device and column. The injection volume was $20 \mu \mathrm{L}$ in the anion system and $100 \mu \mathrm{L}$ in the cation system. Nitric acid solutions were prepared from POCH S.A. (Poland) concentrated weighed amounts, while sodium carbonate and hydrogen carbonate, as well as DPA, were dissolved from solid phase (Merck Millipore).

\subsubsection{Uppsala}

Samples were filtered using $0.22 \mu \mathrm{m}$ polyethersulfone membranes (Minisart ${ }^{\circledR}$, Sartorius) and anion determinations were performed using a Metrohm ProfIC850 ion chromatograph (Metrohm, Herisau, Switzerland), equipped with an autosampler and a Metrosep C4 column. The mobile phase of $0.02 \mathrm{M}$ DPA and $0.1 \mathrm{M} \mathrm{HNO}_{3}$ was run in isocratic flow of $0.7 \mathrm{~mL} \mathrm{~min}^{-1}$. Very low detection limits $\left(\leq 0.006 \mathrm{mg}^{-}\right.$ ${ }^{1} \mathrm{~L}$ ) were achieved thanks to the sample injection volume of $500 \mu \mathrm{L}$.

\subsubsection{Venice}

Anion determination was performed using a Dionex ${ }^{\mathrm{TM}}$ ICS-5000 ion chromatograph (ThermoScientific ${ }^{\mathrm{TM}}$, Waltham, US) equipped with an anionic exchange column (Dionex IonPac AS 11, $2 \times 250 \mathrm{~mm}$ ) and a guard column (Dionex IonPac AG11 $2 \times 50 \mathrm{~mm}$ ). Sodium hydroxide $(\mathrm{NaOH})$, used as a mobile phase, was produced by an eluent generator (Dionex ICS 5000EG, Thermo Scientific). The injection volume was $100 \mu \mathrm{L}$. The IC was coupled to a single quadrupole mass spectrometer (MSQ Plus $^{\mathrm{TM}}$, Thermo Scientific ${ }^{\mathrm{TM}}$ ) with an electrospray source (ESI) that operated in negative mode. To determine cations, a capillary ion chromatograph (Thermo Scientific Dionex ICS-5000), equipped with a capillary cation exchange column (DionexIonPac CS19-4 $\mu \mathrm{m}, 0.4 \times 250 \mathrm{~mm}$ ) and a guard column (Dionex IonPac CG19-4 $\mu \mathrm{m}, 0.4 \times 50 \mathrm{~mm}$ ), was used, coupled to a conductivity detector. The injection volume was $0.4 \mu \mathrm{L}$. All details about the anion and cation methods are reported by (Barbaro et al., 2017).

\subsubsection{Instrumental performance of each laboratory}

For all laboratories, calibration for ions were evaluated using analytical standards (Merck/Sigma Aldrich). The calibrations in each lab gave different linear ranges for each ion due to the different methods used (Table S1). Good linearity was demonstrated in each lab and all calibration curves had $\mathrm{R}^{2}>0.99$. Samples that had ion concentrations beyond the calibration range were diluted with ultrapure water before re-analysis. Analytical blanks of ultrapure water $(>18 \mathrm{M} \Omega \cdot \mathrm{cm})$ were included in the 
analysis at all three labs. The method detection limit (MDL) was set to three times the standard deviation of the blank values (Table S1). For $\mathrm{Na}^{+}, \mathrm{Mg}^{2+}, \mathrm{Cl}^{-}$and $\mathrm{SO}_{4}{ }^{2-}$, values $<\mathrm{MDL}$ occurred in less than $10 \%$ of cases, and for $\mathrm{Ca}^{2+}$ and $\mathrm{NO}_{3}^{-}$the $<\mathrm{MDL}$ concentrations were noted in $12 \%$ and $17 \%$ of cases, respectively. However, $\mathrm{K}^{+}$and $\mathrm{Br}^{-}$were detected only in $53 \%$ and $46 \%$ of all samples, respectively, while $\mathrm{NH}_{4}{ }^{+}$concentration exceeded the MDL only in $36 \%$ of all measurements. For the calculation of bulk ionic loading in snow pits, values $<$ MDL were assumed to be equal to half the MDL.

Accuracy and precision are important parameters to evaluate during method validation. Checks for accuracy were made using certified multi-element standard solutions for anions $\left(\mathrm{F}^{-}, \mathrm{Cl}^{-}, \mathrm{Br}^{-}, \mathrm{NO}_{3}^{-}, \mathrm{SO}_{4}{ }^{2-}\right.$, $\mathrm{n}^{\circ}$ 89886-50ML-F, Sigma Aldrich) and cations $\left(\mathrm{Na}^{+}, \mathrm{K}^{+}, \mathrm{Mg}^{2+}, \mathrm{Ca}^{2+}, \mathrm{n}^{\circ}\right.$ 89316-50ML-F, Sigma Aldrich), at the concentration of $10 \mathrm{mg} \mathrm{L}^{-1} \pm 0.2 \%$. Accuracy is expressed as a relative error calculated as $(\mathrm{Q}-\mathrm{T}) / \mathrm{T} \times 100$, where $\mathrm{Q}$ is the determined value and $\mathrm{T}$ is the "true" value. The accuracy for each ion in all labs was always $< \pm 10 \%$, except for $\mathrm{Mg}^{2+}$ measurements at the Hornsund laboratory. The analytical precision was quantified as the relative standard deviation (RSD) for replicates $(n>3)$ of standard solutions and was always $<10 \%$ for each ion (Table S1).

\subsection{Stable water isotopes}

The determination of stable isotope ratios of $\mathrm{O}$ and $\mathrm{H}$ was performed at Tallinn University of Technology using a Picarro L2120-i water isotope analyser with a high-precision AO211 vaporizer. Results are reported in the standard delta notation as $\delta^{18} \mathrm{O}$ and $\delta^{2} \mathrm{H}$ relative to VSMOW. Reproducibility was $\pm 0.1 \%$ for $\delta^{18} \mathrm{O}$ and $\pm 1 \%$ for $\delta^{2} \mathrm{H}$, respectively. 


\section{Results}

\subsection{Spatial distribution of ionic species}

To investigate differences in snowpack composition across all glaciers, we compared the total mass of ions that accumulated in snow at the different sampling sites. On average, the snow cover season on Svalbard lasts from early September to early May, but snow may also fall in summer months at high elevations. The snow pits in this study were sampled in early to late April 2016 and might therefore not contain the full annual ionic burden, since deposition might occur also in other months. Therefore, we report these data as ionic loads $\left(\mathrm{mg} \mathrm{m}^{-2}\right)$ rather than annual fluxes. In each snow pit, the ionic load was calculated as the cumulative sum of the ionic concentrations multiplied by the snow water equivalent in each discrete layer. The snowpack chemical characteristics were then compared between glacier zones (ablation zone, ELA, and accumulation zone; Table 2, Figure 1).

Snow pits samples collected in the Hornsund area (southern Spitsbergen) showed a markedly higher total load for all major ions (Figures 1 and 2) than at all other sites. The samples collected in the accumulation zones of WB and HB had total ionic loads of 8161 and $8023 \mathrm{mg} \mathrm{m}^{-2}$, respectively, four times higher than those collected in the same zone at KVG (2861 $\left.\mathrm{mg} \mathrm{m}^{-2}\right)$, AF (2607 $\left.\mathrm{mg} \mathrm{m}^{-2}\right)$ and ALB (1934 $\left.\mathrm{mg} \mathrm{m}^{-2}\right)$ and 16 times higher than those sampled at LF $\left(639 \mathrm{mg} \mathrm{m}^{-2}\right)$ and HDF $\left(583 \mathrm{mg} \mathrm{m}^{-2}\right)$. Similar differences were observed for the snow pits collected at lower altitudes (Figure 2).

In the accumulation zone of all glaciers (Figure $\mathrm{S} 1$ ), $\mathrm{Na}^{+}$and $\mathrm{Cl}^{-}$were generally the most abundant ionic species, with percentages ranging from $29 \%$ (HDF) to $36 \%$ (AF) for $\mathrm{Na}^{+}$, and from $34 \%$ (LF) to $48 \%$ ( $\mathrm{HB}$ and $\mathrm{WB}$ ) for $\mathrm{Cl}^{-}$, respectively. The snowpack on Hornsund glaciers ( $\mathrm{HB}, \mathrm{WB}$ ) had higher $\mathrm{Cl}^{-}$ percentages (48-49\%) compared to that of other glaciers (34-39\%), while conversely the $\mathrm{SO}_{4}{ }^{2-}$ percentage was lower there $(9 \%)$ than on other glaciers (11-23\%). The ionic loads were generally highest in the accumulation zone of glaciers, and lowest in the ablation zone (Figure 2), mostly due to the lower snow accumulation and greater wind deflation at lower elevations. This pattern held true for $\mathrm{Na}^{+}, \mathrm{Cl}^{-}, \mathrm{NH}_{4}^{+}$, $\mathrm{K}^{+}, \mathrm{Ca}^{2+}$, and $\mathrm{Mg}^{2+}$ at most glacier sites, except in the Hornsund region. The load of $\mathrm{Br}^{-}$was similar on glaciers of the Ny-Ålesund sector (ALB, HDF, KVG) and on LF, but was higher in AF and Hornsund glaciers (HB, WB; Figure 2). The load of $\mathrm{NO}_{3}{ }^{-}$was similar for all glaciers, except for LF, where very low loads were found. Unlike total $\mathrm{SO}_{4}{ }^{2-}$, the non-sea-salt fraction of sulphate (nss- $\mathrm{SO}_{4}{ }^{2-}$ ), calculated using a seawater $\mathrm{SO}_{4}{ }^{2-}: \mathrm{Na}^{+}$mass ratio of 0.252 , (Millero et al., 2008) showed lower loads on Hornsund glaciers (15-107 $\mathrm{mg} \mathrm{m}^{-2}$ ) when compared to glaciers in other parts of the archipelago (Figure 1, Table 2). The nss- $\mathrm{SO}_{4}{ }^{2-}$ loads varied between $22-131 \mathrm{mg} \mathrm{m}^{-2}$ at $\mathrm{HDF}$ and $\mathrm{LF}, 75-266 \mathrm{mg} \mathrm{m}^{-2}$ at $\mathrm{KVG}$ and ALB, and $153-206 \mathrm{mg} \mathrm{m}^{-2}$ at AF.

\subsection{Stable water isotopes $\left(\delta^{18} \mathrm{O}\right.$ and $\left.\delta^{2} H\right)$}


Our results provide the first picture of spatial variations in the mean stable water isotope composition of the seasonal snowpack across Svalbard (Table 2, Figure S2). The snow water equivalent (SWE)weighted mean $\delta^{18} \mathrm{O}$ and $\delta^{2} \mathrm{H}$ decreased significantly from south to north (Spearman rank correlation $\rho$ with latitude was -0.69 and -0.65 for $\delta^{18} \mathrm{O}$ and $\delta^{2} \mathrm{H}$, with $\mathrm{p}<0.001$ and $\mathrm{p}<0.01$, respectively). The isotopically heaviest snow (least negative $\delta$ values) occurred on glaciers of the Hornsund region $\left(\delta^{18} \mathrm{O}\right.$ : 11.25 to $-9.54 \%$; $\delta^{2} \mathrm{H}$ : -77.62 to $-63.64 \%$ ), and the isotopically lightest (most negative $\delta$ values) in $\mathrm{AF}$ $\left(\delta^{18} \mathrm{O}\right.$ : -16.00 to $-13.89 \%$; $\delta^{2} \mathrm{H}$ : -111.15 to $-96.89 \%$ ). Glacier sites in NW Spitsbergen and on LF had mean $\delta^{18} \mathrm{O}$ and $\delta^{2} \mathrm{H}$ values that fell within these ranges. On KVG, ALB, HDF and LF, the $\delta^{18} \mathrm{O}$ and $\delta^{2} \mathrm{H}$ in snow decreased monotonically (becoming gradually more negative) with increasing elevation. However, on other glaciers this pattern did not hold: on AF, we found an increase from AF1 to AF2, but a decrease from AF2 to AF3; on WB the $\delta^{18} \mathrm{O}$ and $\delta^{2} \mathrm{H}$ were similar at WB1 and WB2, but less negative at WB3. On HB there was no statistical difference between the mean $\delta^{18} \mathrm{O}$ and $\delta^{2} \mathrm{H}$ value in all snow pits. A general, significant anticorrelation with altitude was found for SWE-weighted mean $\delta^{2} \mathrm{H}(\rho=-0.63$, $\mathrm{p}<0.01)$, and $\delta^{18} \mathrm{O}(\rho=-0.65, \mathrm{p}<0.01)$.

\section{Discussion}

There have been few published studies on recent seasonal snow or firn chemistry in Svalbard, hence comparisons of our data with these earlier results are limited to a few sites. (Virkkunen et al., 2007) and (Vega et al., 2015a) and unpublished data) quantified the annual chemical loads of $\mathrm{Na}^{+}, \mathrm{Ca}^{2+}, \mathrm{NO}_{3}{ }^{-}$and nss- $\mathrm{SO}_{4}{ }^{2-}$ at Lomonosovfonna summit (LF3) from 2002 to 2011 using snow and firn cores, and our study extends these data to 2016. The range of annual ionic loads at LF3 over the 15 -year period is remarkably wide, but no clear temporal trend can be identified (Table 3). At Holtedahlfonna summit (HDF3), firn core measurements by (Spolaor et al., 2013) found a mean $\mathrm{Na}^{+}$concentration of $110 \pm 73 \mathrm{ng} \mathrm{g}^{-1}$ over the period 2003-2012, while the mean concentration in the April 2016 snowpack (this study) was $191 \mathrm{ng} \mathrm{g}^{-1}$, hence within the range reported in earlier years.

\subsection{The main ion sources in the Svalbard seasonal snow}

The composition of the Svalbard seasonal snowpack sampled during the C2S3 project clearly indicates that the ocean is the main source of ions in snow, as was shown by Hodgkins and Tranter (2017). At all sites, the dominant ions are $\mathrm{Na}^{+}, \mathrm{Cl}^{-}$, and $\mathrm{SO}_{4}{ }^{2-}$, with comparatively minor amounts of $\mathrm{K}^{+}, \mathrm{Ca}^{2+}$ and $\mathrm{Mg}^{2+}$ (Figure S1). To help clarify the possible sources and modes of deposition of ions in snow, we computed Spearman rank correlations between total ionic loads ( $\left.\rho_{\text {load }}\right)$, as well as between volume-weighted mean ionic concentrations $\left(\rho_{\text {conc }}\right)$, across all snow pits $(n=22$; Table 4$)$. The chemical species that are predominantly wet-deposited and sharing common sources and not undergoing significant composition changes in transport should exhibit similar concentration patterns (high $\rho_{\text {conc }}$ ) (Schüpbach et al., 2018). The concentrations of $\mathrm{Mg}^{2+}, \mathrm{K}^{+}$and $\mathrm{Ca}^{2+}$ were all positively correlated with those of $\mathrm{Na}^{+}$and $\mathrm{Cl}^{-}$, 

which points to both wet and dry deposition being a significant mechanism in their accumulation in snowpack.

The concentrations of $\mathrm{Mg}^{2+}$ were positively and significantly correlated with both $\mathrm{Ca}^{2+}$ and nss-Ca ${ }^{2+}$ ( $\rho_{\text {conc }}$ $=0.70$ and 0.47 , respectively; the latter coefficient was higher for loads at 0.56 ; Table 4 ), suggesting they share some non-marine source(s). Furthermore, all glaciers had greater $\mathrm{Ca}^{2+}: \mathrm{Mg}^{2+}$ ratios than seawater (0.32; (Millero et al., 2008) (Figure 3). It is likely that the excess $\mathrm{Ca}^{2+}$ and $\mathrm{Mg}^{2+}$ came from mineral particles, i.e. $\mathrm{CaCO}_{3}$ (calcite), and local rock (or soil) dust (Kekonen et al., 2005) derived from calcareous rocks, especially limestone, dolostone and marble, which are abundant in (Dallmann, 1999) The presence of carbonate ions in the collected snow samples would explain the missing negative charge in the ionic balance (anion $\mathrm{X}^{-}$; Figure S3).

Sulphate $\left(\mathrm{SO}_{4}{ }^{2-}\right)$ was highly and significantly $(p$-value $<0.05)$ correlated with both $\mathrm{Na}^{+}\left(\rho_{\text {load }}=0.92 ; \rho_{\text {conc }}\right.$ $=0.80)$ and $\mathrm{Cl}^{-}\left(\rho_{\text {load }}=0.93 ; \rho_{\text {conc }}=0.75\right)$, indicating that sea spray is its main source. However $\mathrm{Na}^{+} / \mathrm{SO}_{4}{ }^{2-}$ and $\mathrm{Cl}^{-}: \mathrm{SO}_{4}{ }^{2-}$ ratios were well below seawater values (Millero et al., 2008) on most glaciers except those near Hornsund (WB and HB), suggesting inputs of nss-SO ${ }_{4}^{2-}$ (Figure 3). Biogenic nss-SO ${ }_{4}^{2-}$ can be deposited in the snow as an oxidized by-product of dimethyl sulphide (DMS) emitted by marine algal blooms (Gondwe et al., 2003), typically initiated in April but sometimes later (Ardyna et al., 2013). Another plausible source of nss- $\mathrm{SO}_{4}{ }^{2-}$ deposition in Svalbard is long-range transport of $\mathrm{SO}_{4}{ }^{2-}$ aerosols from biomass burning in the spring, or from fossil fuel combustion throughout the winter (Barrie, 1986; Law and Stohl, 2007; Nawrot et al., 2016). The nss- $\mathrm{SO}_{4}{ }^{2-}$ did not correlate significantly with other ionic species, suggesting a separate origin. An extra consideration is that in the southern region of the

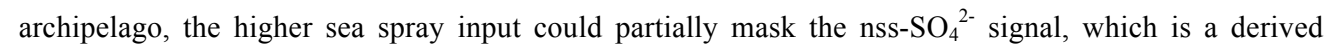
variable, because the larger uncertainty for greater $\mathrm{Na}^{+}$concentrations would disproportionately affect estimations of nss- $\mathrm{SO}_{4}{ }^{2-}$ at these sites.

Bulk ionic loads of $\mathrm{SO}_{4}{ }^{2-}$ in the snow pits were significantly and positively correlated with those of $\mathrm{NO}_{3}{ }^{-}$ $\left(\rho_{\text {load }}=0.55\right)$ and $\mathrm{NH}_{4}^{+}\left(\rho_{\text {load }}=0.68\right)$, but the correlations between weighted mean ionic concentrations were not significant, hinting at co-deposition (wet) rather than shared sources (Table 4). These species are known to form secondary aerosols (Karl et al., 2019; Schaap et al., 2004) and thus their proportions in aerosols may differ significantly from those in their source emissions. It is also possible that nitrogen species underwent further post-depositional photochemical reduction and evasion, thereby reducing their concentrations in snow (Curtis et al., 2018). Finally, we remark here that the snow pit sampling was done in April, earlier than the beginning of the oceanic algal bloom in the surrounding Svalbard basin, which could have led to underrepresentation of biological emissions from late spring in our samples. 
Spatial variations of ammonium loads $\left(\mathrm{NH}_{4}{ }^{+}\right)$across Svalbard glaciers mirrored the pattern shown by sea salt ions, with higher loads in the Hornsund region and lower loads in other areas. This was also reflected by significant correlations between bulk loads of $\mathrm{NH}_{4}{ }^{+}$with those of $\mathrm{Na}^{+}$and $\mathrm{Cl}^{-}\left(\rho_{\text {load }}=0.64\right.$ and 0.73 , respectively), and with $\mathrm{Na}^{+}, \mathrm{K}^{+}$and $\mathrm{Mg}^{2+}$ by concentration $\left(\rho_{\text {conc }}=0.47,0.62\right.$ and 0.47 , respectively), the latter relationships suggesting that some ammonium is deposited as coatings on crustal aerosols (Eastwood et al., 2009). Ammonium has been linked to biogenic, forest fire, and anthropogenic agricultural emissions (Trachsel et al., 2019). The higher annual snowpack load of $\mathrm{NH}_{4}{ }^{+}$, determined in the Hornsund region is more likely connected with biological sources than anthropogenic activities, although some contribution from biomass burning events cannot be excluded. The marine primary productivity in spring 2016 (April and May) was higher in the south-eastern ocean sector of the Svalbard archipelago (Figure S4), which could partially explain the higher $\mathrm{NH}_{4}{ }^{+}$load. This would also explain the correlation between ammonium and sea-salt ions (Table 4). Locally, especially for HB, there may be extra $\mathrm{NH}_{4}{ }^{+}$emissions from bird colonies (Keslinka et al., 2019; Wojczulanis K. et al., 2008).

Unlike $\mathrm{NH}_{4}{ }^{+}$, the bulk loading of $\mathrm{NO}_{3}{ }^{-}$in snow was highest in northwestern Spitsbergen (Ny-Ålesund area), when compared to other parts of Svalbard. Deposition of $\mathrm{NO}_{3}{ }^{-}$in Arctic snow is often associated with the long-range atmospheric transport of $\mathrm{NO}_{x}$ and related $\mathrm{N}$ species from anthropogenic source regions at lower latitudes (Björkman et al., 2014; Fibiger et al., 2016; Vega et al., 2015a). Differences in $\mathrm{NO}_{3}{ }^{-}$loads in snow in various parts of Svalbard might therefore reflect differences in the transport pathways of precipitating air masses, including formation of secondary aerosols, or post-depositional processes, rather than local emissions. While local shipping routes and the settlement of Ny Ålesund itself may contribute $\mathrm{NO}_{3}{ }^{-}$emissions (Winther et al., 2014), the highest share of the total ionic load of $\mathrm{NO}_{3}{ }^{-}$was found in the accumulation zone of $\mathrm{HDF}$ ( $9 \%$ of the total ionic load; Figure S1). Given that HDF is the most remote site from Ny Ålesund relative to KVG or ALB, it should not capture a high share of local pollution. The highest correlation coefficient for $\mathrm{NO}_{3}{ }^{-}$, both in terms of concentrations and loads, was found with nss-Ca ${ }^{2+}$. This would support both the formation of calcium nitrate in the atmosphere (Gibson et al., 2006) or post-depositional processes removing the $\mathrm{NO}_{3}{ }^{-}$from layers poor in $\mathrm{Ca}^{2+}$, since calcium has been hypothesised to stabilise the nitrate in snowpack against post-depositional losses (Kekonen et al., 2017).

\subsection{Chlorine depletion}

Although $\mathrm{Na}^{+}$and $\mathrm{Cl}^{-}$, the main species of sea salt, were significantly correlated ( $\rho_{\text {conc }}=0.95$ ), the values of the $\mathrm{Cl}^{-} / \mathrm{Na}^{+}$ratio in snow were lower than that in seawater on most studied glaciers, except those near Hornsund (Figure 3), suggesting a $\mathrm{Cl}^{-}$deficit at the more northerly sites. A possible explanation of this $\mathrm{Cl}^{-}$deficit might be de-chlorination of the sea spray aerosol during transport or, less likely, at the snowatmosphere interface. This reaction occurs between sea salt particles, containing $\mathrm{NaCl}$, and $\mathrm{NO}_{3}{ }^{-}, \mathrm{SO}_{4}{ }^{2-}$, or organic acids to release gaseous $\mathrm{HCl}$ (Zhuang et al., 1999). We calculated the percentage of $\mathrm{Cl}^{-}$ 
depletion $\left(\mathrm{Cl}_{\text {dep }}^{-}\right)$as $\mathrm{Cl}_{\text {dep }}^{-}=\left(\mathrm{Cl}_{\mathrm{ss}}^{-}-\mathrm{Cl}_{\text {meas }}^{-}\right) / \mathrm{Cl}_{\text {ss }}^{-} \times 100 \%$, where $\mathrm{Cl}_{\text {ss }}^{-}=1.174 \mathrm{Na}_{\text {meas }}^{+}$, and $\mathrm{Cl}_{\text {meas }}^{-}$and $\mathrm{Na}^{+}{ }_{\text {meas }}$ are the measured equivalent concentrations (Yao et al., 2003). Except for site HDF2 $\left(\mathrm{Cl}^{-}{ }_{\text {dep }}=2 \%\right)$, the lowest mean $\mathrm{Cl}_{\text {dep }}^{-}$values were obtained for Hornsund glaciers (WB, HB: 10-19\%), while values at other glacier sites ranged between 21 and 75\% (Table 2). This suggests that sea-salt aerosols travel along a route from southern to northern Svalbard, which gives more time for $\mathrm{Cl}^{-}$depletion in the ionic mixtures reaching more northerly locations.

\subsection{Bromine enrichment}

In addition to $\mathrm{Cl}^{-}$, snowfall can scavenge $\mathrm{Br}^{-}$(Peterson et al., 2019; Spolaor et al., 2019), and $\mathrm{Br}^{-}$loads on Svalbard glaciers surveyed in April 2016 were positively and significantly correlated with those of primary sea salt ions $\mathrm{Na}^{+}\left(\rho_{\text {load }}=0.48\right), \mathrm{Cl}^{-}\left(\rho_{\text {load }}=0.53\right)$ and $\mathrm{Mg}^{2+}\left(\rho_{\text {load }}=0.51\right)$ (Table 4). Correlations between weighted mean concentrations were not significant, however, suggesting departures of the $\mathrm{Br}$ concentrations in snow from typical seawater ionic ratios at some glacier sites. A Br- enrichment factor $\left(\mathrm{Br}_{\text {enr }}\right)$ can be calculated as $\mathrm{Br}_{\text {enr }}=\mathrm{Br}^{-} /\left(0.0065 \mathrm{Na}^{+}\right)$, where 0.0065 is the $\mathrm{Br}^{-}: \mathrm{Na}^{+}$seawater mass ratio (Maffezzoli et al., 2017). The $\mathrm{Br}_{\text {enr }}$ reflects specific processes (in particular sea ice $\mathrm{Br}$ emission) that affect the $\mathrm{Br}^{-}$concentration and load in the snowpack (Spolaor et al., 2014). Results of our calculations (Table 2, Figure S5) show that on glaciers of the Hornsund area (HB and WB) and NW Spitsbergen (KVG, ALB and HDF), the mean $\mathrm{Br}_{\text {enr }}$ values are often, but not always, $<1$, indicating some $\mathrm{Br}^{-}$ depletion, in agreement with the findings of (Jacobi et al., 2019) for glaciers in the Ny Ålesund area. The depletion could be a result of snowpack $\mathrm{Br}$ re-emission, but this seems unlikely since field measurements near Ny-Ålesund found no evidence of such volatilization of snow-bound Br (Spolaor et al., 2019).

Alternatively, $\mathrm{Br}^{-}$depletion could occur through $\mathrm{BrO}$ loss from marine aerosols and subsequent deposition of these Br-depleted aerosols in snow. In contrast to southern and northwestern Spitsbergen, glaciers in central Spitsbergen (LF) and in Nordaustlandet (AF), showed $\mathrm{Br}_{\text {enr }}$ values $>1$. These glaciers lie relatively close to areas to the east of the archipelago that are often covered by first-year sea ice. Newly-formed sea ice has been shown to release gas phase $\mathrm{Br}$ into the polar atmosphere, thus supplying an extra $\mathrm{Br}$ source in addition to sea spray (Spolaor et al., 2016). The spatial distribution of the $\mathrm{Br}$ enriched snow pit sites supports this : sites closest to areas covered by first-year sea ice have the largest $\mathrm{Br}$ enrichments, and the latter decrease with greater distance from the eastern shores of Svalbard (Figure S5). A survey of the average sea ice coverage in the period March-May 2016, which is relevant to the $\mathrm{Br}$ enrichment phenomenon (data by Norwegian Meteorological Institute) confirms that the north-eastern and eastern shore of Svalbard were indeed covered much more frequently by close and open drift ice than the south or north-west.

\subsection{Distribution pattern of $\delta^{18} \mathrm{O}$ and $\delta^{2} \mathrm{H}$}


As described earlier, the SWE-weighted mean $\delta^{18} \mathrm{O}$ and $\delta^{2} \mathrm{H}$ values in glacier snow pits decreased significantly with increasing latitude across Svalbard, the least negative values occurring on glaciers of the Hornsund region, and the most negative in Austfonna (Table 2). This pattern follows the climate gradient across the archipelago, milder in the south, colder in the north. Part of the south-north contrast in $\delta$ values could be explained by the lower mean altitude of glacier sites in the Hornsund region compared to some of the higher-elevation sites further north on Spitsbergen or on Austfonna, and the relationship with elevation was similar for both isotopic ratios in the collected dataset.

The deuterium excess $\left(d=\delta^{2} \mathrm{H}-\left(8 * \delta^{18} \mathrm{O}\right)\right)$ is mainly influenced by the source region of the precipitating moisture and in particular by the sea surface temperature. In addition, $d$ is also influenced by the temperature gradient between the moisture source and precipitation area. The SWE-weighted mean $d$ values in Svalbard snow pits varied within a relatively narrow range of 6.74\%o (from 10.10 to $16.84 \%$ ), and similarly to $\delta^{18} \mathrm{O}$, showed no clear gradient with elevation or longitude. Deuterium excess showed a significant correlation with latitude, at $\rho=0.60(\mathrm{p}<0.01)$. A more detailed analysis of $d$ by latitude showed that only beyond $79.2^{\circ} \mathrm{N}$, i.e. in Austfonna snow pits, was $d$ significantly different than at other sites (Kruskal-Wallis test, $\mathrm{z}=4.23, \mathrm{p}<0.04$ ). This is consistent with lower temperatures and evaporation rates in the more northern waters around Svalbard, and suggests that snowfall on AF is at least partly affected by a different, more northerly moisture source than the rest of the archipelago.

\subsection{Effect of elevation: a case study of $\mathrm{Na}$}

The glacier survey carried out during the $\mathrm{C} 2 \mathrm{~S} 3$ project afforded the opportunity to investigate the possible effect of elevation on the ionic composition of the snowpack. To do this, we compared the bulk load and SWE-weighted mean concentration of $\mathrm{Na}^{+}$across all studied snow pits, ordered by elevation (Figure 4). Overall, both $\mathrm{Na}^{+}$loads and concentrations decreased with increasing altitude ( $\rho_{\text {load }}=-0.24, \mathrm{p}$ $\left.>0.05 ; \rho_{\text {conc }}=-0.72, \mathrm{p}<0.05\right)$. This likely reflects greater local sea spray aerosol deposition at lower, compared to higher, glacier sites. We then computed linear (Pearson) correlation coefficients ( $R$, with associated $p$-values) between log-transformed $\mathrm{Na}^{+}$loadings $\left(\log \left(\mathrm{Na}_{\text {load }}\right)\right)$ and $\delta^{18} \mathrm{O}$ for all snow pits in the accumulation zones of glaciers (Figure 5). The calculation was performed with all snow layers. The $\mathrm{Na}^{+}$ load was used as sea-spray tracer, while the $\delta^{18} \mathrm{O}$ was assumed to vary with moisture source between discrete snowfall events. We found that the positive correlation between $\log \left(\mathrm{Na}_{\text {load }}\right)$ and $\delta^{18} \mathrm{O}$ increased with elevation from $R=0.1$ (HB3; $396 \mathrm{~m}$ a.s.1.) to $R=0.65$ (LF3; $1193 \mathrm{~m}$ a.sl.), and reached a $95 \%$ threshold of significance $(R>0.3)$ for glaciers sites above $600 \mathrm{~m}$ a.sl. (KVG, AF, LF and HDF; Figure $5)$. The average distance was a comparatively negligible factor in explaining the correlation between $\log \left(\mathrm{Na}_{\text {load }}\right)$ and $\delta^{18} \mathrm{O}$.

The increase in strength and significance of the $\log \left(\mathrm{Na}_{\text {load }}\right)-\delta^{18} \mathrm{O}$ correlation with altitude might be explained by different contributions of locally-emitted $\mathrm{ssNa}^{+}$, relative to those of $\mathrm{Na}^{+}$from more distant sources. Sites located at lower altitudes are proportionally more affected by local sea spray deposition, 
with or without snowfall. Conversely, sites at higher elevations likely receive a larger share of their ionic load from more distant sources, and by wet deposition through snowfall. At the four sites (KVG, AF, LF and HDF) where the $\log \left(\mathrm{Na}_{\text {load }}\right)-\delta^{18} \mathrm{O}$ correlation was significant, increases in $\delta^{18} \mathrm{O}$ in snow layers were often associated with higher $\mathrm{Na}^{+}$concentrations. The isotopically heavier (less negative) $\delta^{18} \mathrm{O}$ values suggests that the co-registered $\mathrm{Na}^{+}$enhancements were associated with precipitation of relatively warm air, probably advected from lower latitudes. Air masses arriving from the south travel across the ocean for an extended time, which can enrich them in sea spray aerosol and hence in $\mathrm{Na}^{+}$. It is also possible that the poorer $\log \left(\mathrm{Na}_{\text {load }}\right)-\delta^{18} \mathrm{O}$ correlation at lower altitude glacier sites is partly due to stronger postdepositional modification of isotopic and ionic signals in snowpack related to more frequent meltrefreeze episodes.

\section{Summary and Conclusion}

We have quantified and described, for the first time, the spatial distribution of major ion loads $\left(\mathrm{Ca}^{2+}, \mathrm{K}^{+}\right.$, $\mathrm{Na}^{2+}, \mathrm{Mg}^{2+}, \mathrm{NH}_{4}{ }^{+}, \mathrm{SO}_{4}{ }^{2-}, \mathrm{Br}^{-}, \mathrm{Cl}^{-}$and $\left.\mathrm{NO}_{3}{ }^{-}\right)$and variations of $\delta^{18} \mathrm{O}$ and $\delta^{2} \mathrm{H}$ in the snowpack on glaciers across Svalbard for a single accumulation season (2015-2016). The highest total ionic loads were found in the southern region of Spitsbergen (Hornsund area), and exceeded $8 \mathrm{~g} \mathrm{~m}^{-2}$. Conversely, the lowest total ionic loads $\left(\leq 0.6 \mathrm{~g} \mathrm{~m}^{-2}\right)$ were found at sites in central or northwestern Spitsbergen (LF and HDF). Sea salt ions $\left(\mathrm{Cl}^{-}, \mathrm{Na}^{+}\right.$and $\left.\mathrm{SO}_{4}{ }^{2-}\right)$ dominated the ionic loads at all sites, but their share was highest at sites near Hornsund, for e.g., $48 \% \mathrm{Cl}^{-}$, compared to only $29 \%$ on Holtedahlfonna. Relatively elevated $\mathrm{Ca}^{2+} / \mathrm{Mg}^{2+}$ ratios in snow at all sites indicated non-sea-salt $\mathrm{Ca}^{2+}$ inputs, most likely in the form of carbonate dust. Unlike other ions, $\mathrm{NO}_{3}{ }^{-}$had the highest loads in glaciers of northwestern Spitsbergen, and the lowest at $\mathrm{LF}$. The nitrogen species, $\mathrm{NO}_{3}{ }^{-}$and $\mathrm{NH}_{4}{ }^{+}$, showed distinct spatial distribution patterns. The highest $\mathrm{NO}_{3}{ }^{-}$loads were found in the northwestern part of Svalbard, while the highest $\mathrm{NH}_{4}{ }^{+}$loads were in the southwest. Bromide $\left(\mathrm{Br}^{-}\right)$was most enriched in snow relative to seawater at AF and LF, the glacier sites located closest to areas with first-year sea ice cover. This supports first-year sea ice being an important source of non-sea salt $\mathrm{Br}^{-}$in the polar atmosphere.

An increasing, positive correlation between $\log \left(\mathrm{Na}_{\text {load }}\right)$ and $\delta^{18} \mathrm{O}$ as a function of elevation sites suggests that locations above $600-700 \mathrm{~m}$ a.s.1. are influenced by a proportionally higher share of ions from distant sources, while the lower sites are exposed to more local sources, especially sea spray. These findings confirm that the optimal sites to study the effects of long-range pollution deposition in Svalbard are those found at higher elevations sites, such as the accumulation zones of HDF or LF, because they are the least impacted by the local aerosol emissions. The current study gives the first picture of the ionic composition in the Svalbard snowpack in different regions across the archipelago, in the context of which processes are relevant in controlling the annual snowpack chemical composition there, especially the influence of local and long-range transport. 


\section{Acknowledgements}

The work developed here was supported through grants 246731/E10 and 257636/E10 from the Svalbard Science Forum /(Research Council of Norway), by the Gothenburg Centre of Advanced Studies, BECC Biodiversity and Ecosystem Services in a Changing Climate, Gothenburg Air and Climate Centre, International Arctic Science Committee - Cryosphere working group and the Norwegian Polar Institute. Part of fieldwork has been conducted thanks to the funds of the Leading National Research Centre (KNOW) in Poland, received by the Centre for Polar Studies for the period 2014-2018. This research was also partially supported within statutory activities No 3841/E-41/S/2020 of the Ministry of Science and Higher Education of Poland. The project has received further funding from the European Union's Horizon 2020 research and innovation programme under grant agreement no. 689443 via project iCUPE (Integrative and Comprehensive Understanding on Polar Environments). 
Aas, K. S., Dunse, T., Collier, E., Schuler, T. V., Berntsen, T. K., Kohler, J., and Luks, B.: The climatic mass balance of Svalbard glaciers: a 10-year simulation with a coupled atmosphere-glacier mass balance model, The Cryosphere, 10, 1089-1104, 2016.

Ardyna, M., Babin, M., Gosselin, M., Devred, E., Bélanger, S., Matsuoka, A., and Tremblay, J.-E.: Parameterization of vertical chlorophyll a in the Arctic Ocean: impact of the subsurface chlorophyll maximum on regional, seasonal, and annual primary production estimates, Biogeosciences, 10, 43834404, 2013.

Barbante, C., Spolaor, A., Cairns, W. R. L., and Boutron, C.: Man's footprint on the Arctic environment as revealed by analysis of ice and snow, Earth-Sci Rev, 168, 218-231, 2017.

Barbaro, E., Spolaor, A., Karroca, O., Park, K.-T., Martma, T., Isaksson, E., Kohler, J., Gallet, J. C., Bjorkman, M. P., Cappelletti, D., Spreen, G., Zangrando, R., Barbante, C., and Gambaro, A.: Free amino acids in the Arctic snow and ice core samples: Potential markers for paleoclimatic studies, Sci Total Environ, 607-608, 454-462, 2017.

Barrie, L. A.: Arctic air pollution: An overview of current knowledge, Atmospheric Environment (1967), 20, 643-663, 1986.

Björkman, M. P., Vega, C. P., Kühnel, R., Spataro, F., Ianniello, A., Esposito, G., Kaiser, J., Marca, A., Hodson, A., Isaksson, E., and Roberts, T. J.: Nitrate postdeposition processes in Svalbard surface snow, Journal of Geophysical Research: Atmospheres, 119, 12,953-912,976, 2014.

Brage, B. H., Ketil Isaksen, Rasmus E. Benestad, Jack Kohler, Åshild Ø Pedersen, Leif E Loe, Stephen J. Coulson, Jan Otto Larsen, and Varpe., Ø.: Warmer and wetter winters: characteristics and implications of an extreme weather event in the High Arctic, Environ. Res. Lett., 9, 2014.

Brimblecombe, P., Clegg, S. L., Davies, T. D., Shooter, D., and Tranter, M.: Observations of the preferential loss of major ions from melting snow and laboratory ice, Water Research, 21, 1279-1286, 1987.

Cogley, J. G., R. Hock, L.A. Rasmussen, A.A. Arendt, A. Bauder, R.J. Braithwaite, P. Jansson, G. Kaser, M. Möller, Nicholson, L., and Zemp., M.: Glossary of Glacier Mass Balance and Related Terms, IHP-VII Technical Documents in Hydrology, IACS Contribution No. 2, Unesco-IHP, Paris, $86,2011$.

Curtis, C. J., Kaiser, J., Marca, A., Anderson, N. J., Simpson, G., Jones, V., and Whiteford, E.: Spatial variations in snowpack chemistry, isotopic composition of NO3- and nitrogen deposition from the ice sheet margin to the coast of western Greenland, Biogeosciences, 15, 529-550, 2018.

Dahlke, S., Hughes, N. E., Wagner, P. M., Gerland, S., Wawrzyniak, T., Ivanov, B., and Maturilli, M.: The observed recent surface air temperature development across Svalbard and concurring footprints in local sea ice cover, International Journal of Climatology, n/a, 2020.

Dallmann, W. K.: The geology of Svalbard, Norwegian Polar Institute, 1999.

Eastwood, M. L., Cremel, S., Wheeler, M., Murray, B. J., Girard, E., and Bertram, A. K.: Effects of sulfuric acid and ammonium sulfate coatings on the ice nucleation properties of kaolinite particles, Geophys Res Lett, 36, 2009.

Eneroth, K., Kjellström, E., and Holmén, K.: A trajectory climatology for Svalbard; investigating how atmospheric flow patterns influence observed tracer concentrations, Physics and Chemistry of the Earth, Parts A/B/C, 28, 1191-1203, 2003.

Fibiger, D. L., Dibb, J. E., Chen, D., Thomas, J. L., Burkhart, J. F., Huey, L. G., and Hastings, M. G.: Analysis of nitrate in the snow and atmosphere at Summit, Greenland: Chemistry and transport, Journal of Geophysical Research: Atmospheres, 121, 5010-5030, 2016.

Forland, E. J., Benestad, R., Hanssen-Bauer, I., Haugen, J. E., and Skaugen, T. E.: Temperature and Precipitation Development at Svalbard 1900\&\#8211;2100, Advances in Meteorology, 2011, 14, 2011.

Forsström, S., Ström, J., Pedersen, C. A., Isaksson, E., and Gerland, S.: Elemental carbon distribution in Svalbard snow, Journal of Geophysical Research: Atmospheres, 114, 2009.

Gallet, J. C., Bjorkman, M. P., Larose, C., Luks, B., Martma, T., and Zdanowicz, C.: Protocols and recommendations for the measurement of snow physical properties, and sampling of snow for black carbon, water isotopes, major ions and microorganisms, Norsk Polarinstitutt, 46, 2018. 
Gibson, E. R., Hudson, P. K., and Grassian, V. H.: Physicochemical Properties of Nitrate Aerosols: Implications for the Atmosphere, The Journal of Physical Chemistry A, 110, 11785-11799, 2006.

Gondwe, M., Krol, M., Gieskes, W., Klaassen, W., and de Baar, H.: The contribution of ocean-leaving DMS to the global atmospheric burdens of DMS, MSA, SO2, and NSS SO4=, Global Biogeochem Cy, 17, 2003.

Goto-Azuma, K., Nakawo, M., Jinkang, H., Watanabe, O., and Azuma, N.: Melt-induced relocation of ions in glaciers and in a seasonal snowpack, Snow Ice Cover. Interact with Atmos. Ecosyst., 223, 287-297, 1994.

Hodgkins, R. and Tranter, M.: Solute in high arctic glacier snow cover and its impact on runoff chemistry, Annals of Glaciology, 26, 156-160, 2017.

Isaksen, K., Nordli, Ø., Førland, E. J., Łupikasza, E., Eastwood, S., and Niedźwiedź, T.: Recent warming on Spitsbergen-Influence of atmospheric circulation and sea ice cover, Journal of Geophysical Research: Atmospheres, 121, 11,913-911,931, 2016.

Isaksson, E., Hermanson, M., Hicks, S., Igarashi, M., Kamiyama K, Moore, J., Motoyama, H., Muir, D., Pohjola, V., Vaikmae, R., Van de Wal, R. S. W., and Watanabe, O.: Ice cores from Svalbard-useful archives of past climate and pollution history, 28, 1217-1228, 2003.

Jacobi, H. W., Obleitner, F., Da Costa, S., Ginot, P., Eleftheriadis, K., Aas, W., and Zanatta, M.: Deposition of ionic species and black carbon to the Arctic snowpack: combining snow pit observations with modeling, Atmos. Chem. Phys., 19, 10361-10377, 2019.

Karl, M., Leck, C., Mashayekhy Rad, F., Bäcklund, A., Lopez-Aparicio, S., and Heintzenberg, J.: New insights in sources of the sub-micrometre aerosol at Mt. Zeppelin observatory (Spitsbergen) in the year 2015, Tellus B: Chemical and Physical Meteorology, 71, 1613143, 2019.

Kekonen, T., Moore, J., Perämäki, P., Mulvaney, R., Isaksson, E., Pohjola, V., and van de Wal, R. S. W.: The 800 year long ion record from the Lomonosovfonna (Svalbard) ice core, Journal of Geophysical Research: Atmospheres, 110, 2005.

Kekonen, T., Moore, J. C., Mulvaney, R., Isaksson, E., Pohjola, V., and van de Wal, R. S. W.: A 800 year record of nitrate from the Lomonosovfonna ice core, Svalbard, Annals of Glaciology, 35, 261$265,2017$.

Keslinka, L. K., Wojczulanis-Jakubas, K., Jakubas, D., and Neubauer, G.: Determinants of the little auk (Alle alle) breeding colony location and size in W and NW coast of Spitsbergen, PLOS ONE, 14, e0212668, 2019.

Kuhn, M.: The nutrient cycle through snow and ice, a review, Aquatic Sciences, 63, 150-167, 2001.

Kühnel, R., Roberts, T. J., Björkman, M. P., Isaksson, E., Aas, W., Holmén, K., and Ström, J.: 20-Year Climatology of NO3 and NH4+ Wet Deposition at Ny-Alesund, Svalbard, Advances in Meteorology, $2011,10,2011$.

Law, K. S. and Stohl, A.: Arctic Air Pollution: Origins and Impacts, Science, 315, 1537, 2007.

Maturilli, M., Herber, A., and König-Langlo, G.: Climatology and time series of surface meteorology in Ny-Älesund, Svalbard, Earth Syst. Sci. Data, 5, 155-163, 2013.

Millero, F. J., Feistel, R., Wright, D. G., and McDougall, T. J.: The composition of Standard Seawater and the definition of the Reference-Composition Salinity Scale, Deep Sea Research Part I: Oceanographic Research Papers, 55, 50-72, 2008.

Möller, M. and Kohler, J.: Differing Climatic Mass Balance Evolution Across Svalbard Glacier Regions Over 1900-2010, Frontiers in Earth Science, 6, 128, 2018.

Nawrot, A. P., Migała, K., Luks, B., Pakszys, P., and Głowacki, P.: Chemistry of snow cover and acidic snowfall during a season with a high level of air pollution on the Hans Glacier, Spitsbergen, Polar Science, 10, 249-261, 2016.

Nordli, Ø., Przybylak, R., Ogilvie, A. E. J., and Isaksen, K.: Long-term temperature trends and variability on Spitsbergen: the extended Svalbard Airport temperature series, 1898-2012, Polar Res, 33, 21349, 2014.

Peterson, P. K., Hartwig, M., May, N. W., Schwartz, E., Rigor, I., Ermold, W., Steele, M., Morison, J. H., Nghiem, S. V., and and Pratt, K. A.: Snowpack measurements suggest role for multi-year sea ice regions in Arctic atmospheric bromine and chlorine chemistry, Elem Sci Anth, 7(1), 14, 2019.

Pohjola, V. A., Moore, J. C., Isaksson, E., Jauhiainen, T., van de Wal, R. S. W., Martma, T., Meijer, H. A. J., and Vaikmäe, R.: Effect of periodic melting on geochemical and isotopic signals in an ice core 
from Lomonosovfonna, Svalbard, Journal of Geophysical Research: Atmospheres, 107, ACL 1-1ACL 1-14, 2002.

Rinke, A., Maturilli, M., Graham, R. M., Matthes, H., Handorf, D., Cohen, L., Hudson, S. R., and Moore, J. C.: Extreme cyclone events in the Arctic: Wintertime variability and trends, Environ Res Lett, 12, 094006, 2017.

Schaap, M., van Loon, M., ten Brink, H. M., Dentener, F. J., and Builtjes, P. J. H.: Secondary inorganic aerosol simulations for Europe with special attention to nitrate, Atmos. Chem. Phys., 4, 857-874, 2004.

Schüpbach, S., Fischer, H., Bigler, M., Erhardt, T., Gfeller, G., Leuenberger, D., Mini, O., Mulvaney, R., Abram, N. J., Fleet, L., Frey, M. M., Thomas, E., Svensson, A., Dahl-Jensen, D., Kettner, E., Kjaer, H., Seierstad, I., Steffensen, J. P., Rasmussen, S. O., Vallelonga, P., Winstrup, M., Wegner, A., Twarloh, B., Wolff, K., Schmidt, K., Goto-Azuma, K., Kuramoto, T., Hirabayashi, M., Uetake, J., Zheng, J., Bourgeois, J., Fisher, D., Zhiheng, D., Xiao, C., Legrand, M., Spolaor, A., Gabrieli, J., Barbante, C., Kang, J. H., Hur, S. D., Hong, S. B., Hwang, H. J., Hong, S., Hansson, M., Iizuka, Y., Oyabu, I., Muscheler, R., Adolphi, F., Maselli, O., McConnell, J., and Wolff, E. W.: Greenland records of aerosol source and atmospheric lifetime changes from the Eemian to the Holocene, Nature Communications, 9, 1476, 2018.

Semb, A., Brækkan, R., and Joranger, E.: Major ions in Spitsbergen snow samples, Geophys Res Lett, 11, 445-448, 1984.

Spolaor, A., Barbaro, E., Cappelletti, D., Turetta, C., Mazzola, M., Giardi, F., Björkman, M. P., Lucchetta, F., Dallo, F., Pfaffhuber, K. A., Angot, H., Dommergue, A., Maturilli, M., Saiz-Lopez, A., Barbante, C., and Cairns, W. R. L.: Diurnal cycle of iodine, bromine, and mercury concentrations in Svalbard surface snow, Atmos. Chem. Phys., 19, 13325-13339, 2019.

Spolaor, A., Barbaro, E., Christille, J. M., Kirchgeorg, T., Giardi, F., Cappelletti, D., Turetta, C., Bernagozzi, A., Björkman, M. P., Bertolini, E., and Barbante, C.: Evolution of the Svalbard annual snow layer during the melting phase, Rendiconti Lincei, doi: 10.1007/s12210-015-0500-8, 2016. 1-8, 2016.

Spolaor, A., Gabrieli, J., Martma, T., Kohler, J., Björkman, M. B., Isaksson, E., Varin, C., Vallelonga, P., Plane, J. M. C., and Barbante, C.: Sea ice dynamics influence halogen deposition to Svalbard, The Cryosphere, 7, 1645-1658, 2013.

Spolaor, A., Vallelonga, P., Gabrieli, J., Martma, T., Björkman, M. P., Isaksson, E., Cozzi, G., Turetta, C., Kjær, H. A., Curran, M. A. J., Moy, A. D., Schönhardt, A., Blechschmidt, A. M., Burrows, J. P., Plane, J. M. C., and Barbante, C.: Seasonality of halogen deposition in polar snow and ice, Atmos. Chem. Phys., 14, 9613-9622, 2014.

Thompson, L. G., Mosley-Thompson, E., Davis, M. E., Henderson, K. A., Brecher, H. H., Zagorodnov, V. S., Mashiotta, T. A., Lin, P.-N., Mikhalenko, V. N., Hardy, D. R., and Beer, J. r.: Kilimanjaro Ice Core Records: Evidence of Holocene Climate Change in Tropical Africa, Science, 298, 589-593, 2002.

Trachsel, J. C., Avak, S. E., Edebeli, J., Schneebeli, M., Bartels-Rausch, T., Bruetsch, S., and Eichler, A.: Microscale Rearrangement of Ammonium Induced by Snow Metamorphism, Frontiers in Earth Science, 7, 194, 2019.

van Pelt, W., Pohjola, V., Pettersson, R., Marchenko, S., Kohler, J., Luks, B., Hagen, J. O., Schuler, T. V., Dunse, T., Noël, B., and Reijmer, C.: A long-term dataset of climatic mass balance, snow conditions, and runoff in Svalbard (1957-2018), The Cryosphere, 13, 2259-2280, 2019.

Vecchiato, M., Barbaro, E., Spolaor, A., Burgay, F., Barbante, C., Piazza, R., and Gambaro, A.: Fragrances and PAHs in snow and seawater of Ny-Ålesund (Svalbard): Local and long-range contamination, Environmental Pollution, 242, 1740-1747, 2018.

Vega, C. P., Björkman, M. P., Pohjola, V. A., Isaksson, E., Pettersson, R., Martma, T., Marca, A., and Kaiser, J.: Nitrate stable isotopes in snow and ice samples from four Svalbard sites, Polar Res, 34, 2015a.

Vega, C. P., Pohjola, V. A., Beaudon, E., Claremar, B., van Pelt, W. J. J., Pettersson, R., Isaksson, E., Martma, T., Schwikowski, M., and Bøggild, C. E.: A synthetic ice core approach to estimate ion relocation in an ice field site experiencing periodical melt; a case study on Lomonosovfonna, Svalbard, The Cryosphere Discuss., 9, 5053-5095, 2015b. 
Virkkunen, K., Moore, J. C., Isaksson, E., Pohjola, V., Perämäki, P., Grinsted, A., and Kekonen, T.: Warm summers and ion concentrations in snow: comparison of present day with Medieval Warm Epoch from snow pits and an ice core from Lomonosovfonna, Svalbard, J Glaciol, 53, 623-634, 2007.

Winther, J.-G., Bruland, O., Sand, K., Gerland, S., Marechal, D., Ivanov, B., Gøowacki, P., and König, M.: Snow research in Svalbard-an overview, Polar Res, 22, 125-144, 2003.

Winther, M., Christensen, J. H., Plejdrup, M. S., Ravn, E. S., Eriksson, Ó. F., and Kristensen, H. O.: Emission inventories for ships in the arctic based on satellite sampled AIS data, Atmos Environ, 91, $1-14,2014$.

Wojczulanis K., Jakubas D., and Stempniewicz, L.: Avifauna of Hornsund area, SW Spitsbergen:present state and recent changes, Polish Polar Research, 29, 187-197, 2008.

Wolff, E. W., Barbante, C., Becagli, S., Bigler, M., Boutron, C. F., Castellano, E., De Angelis, M., Federer, U., Fischer, H., and Fundel, F.: Changes in environment over the last 800,000 years from chemical analysis of the EPICA Dome C ice core, Quaternary Sci Rev, 29, 285-295, 2010.

Zhuang, H., Chan, C. K., Fang, M., and Wexler, A. S.: Formation of nitrate and non-sea-salt sulfate on coarse particles, Atmos Environ, 33, 4223-4233, 1999. 
TABLES

Table 1. Table 1. laciers and sampling sites included in this study with their main characteristic. AWS:

654 atmospheric weather station; UiO: University of Oslo; ThèMA: Thèoriser \& Modèliser pour Amènager,

655 University of Franche-Comté; NPI: Norwegian Polar Institute; IMAU: Institute for Marine and Atmospheric

656 Research, Utrecht University; UoS: University of Silesia, IG PAS - Institute of Geophysics, Polish 657 Academy of Sciences; CNR - Consiglio Nazionale delle Ricerche. . The seven glaciers were considered at

658 three different altitudes: 1) lower ablation zone; 2) ELA; 3) upper accumulation zone. Exceptionally, two snow pits (KVG 1 and KVG 1.5) were dug in the ablation zone of Kongsvegen glacier.

660

Table 2. Total load $\left(\mathrm{mg} \mathrm{m}^{-2}\right)$ of major ions, calculated as the sum of loads in all layers of each snow pit. Sea

662 $675>0.05$. 
678 Figure 1. Total snowpack loads $\left(\mathrm{mg} \mathrm{m}^{-2}\right)$ of major ions in 22 snow pits collected on glaciers during the $\mathrm{C} 2 \mathrm{~S} 3$ project. Seven glaciers were sampled in three snow pits in the lower ablation zone (1), near the equilibrium line (2) and in the upper accumulation zone (3), except on Kongsvegen glacier (KVG) where there was an extra snow pit sampled within the ablation zone. Glacier site abbreviations are given in Table 1.

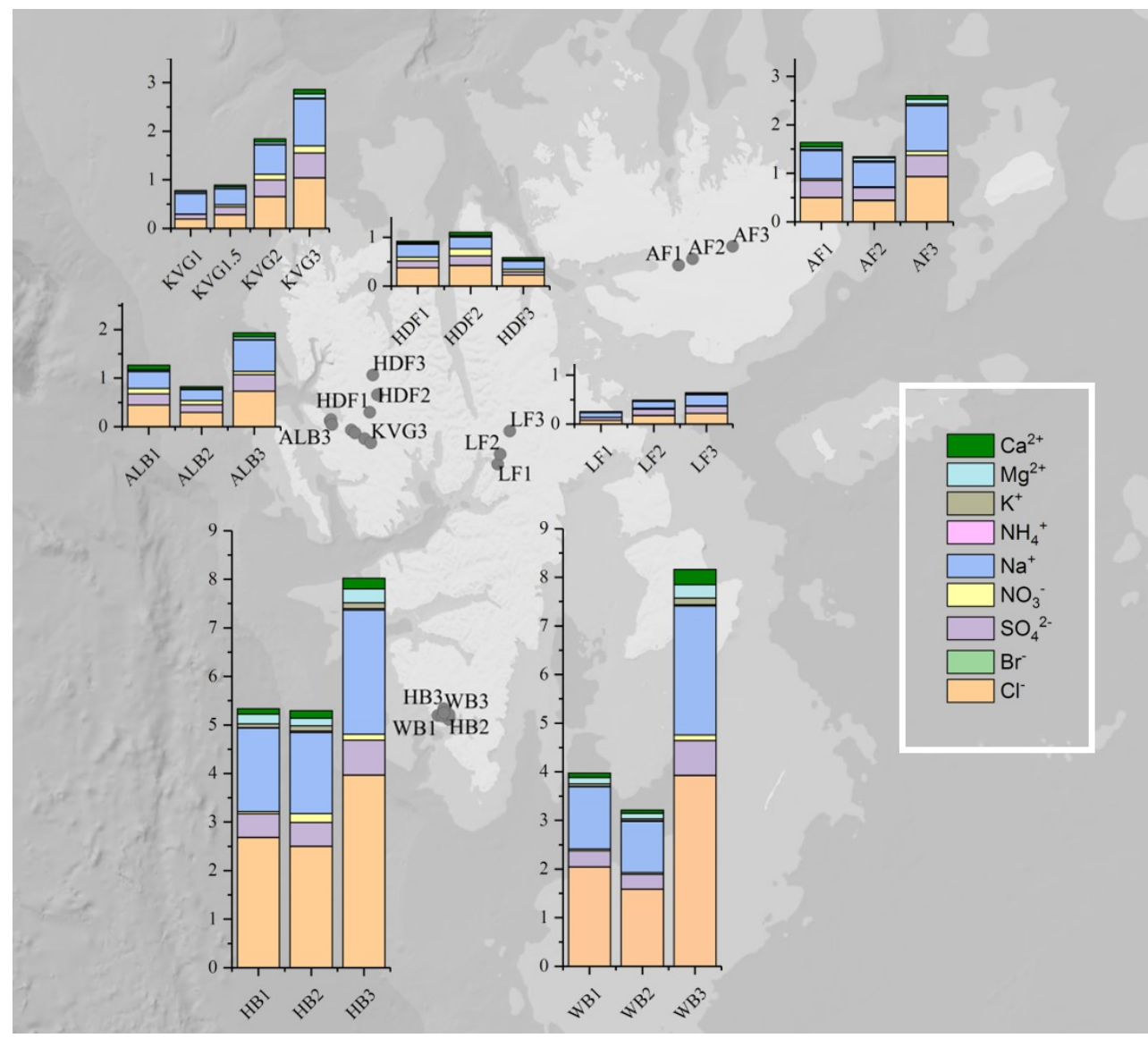


Figure 2. Calculated ionic loads in the snowpack $\left(\mathrm{mg} \mathrm{m}^{-2}\right)$ at the 7 glacier sites sampled during the $\mathrm{C} 2 \mathrm{~S} 3$

689 project. Snow pits for each glacier are marked with the same colour and ordered from lower (left) to higher

690

691
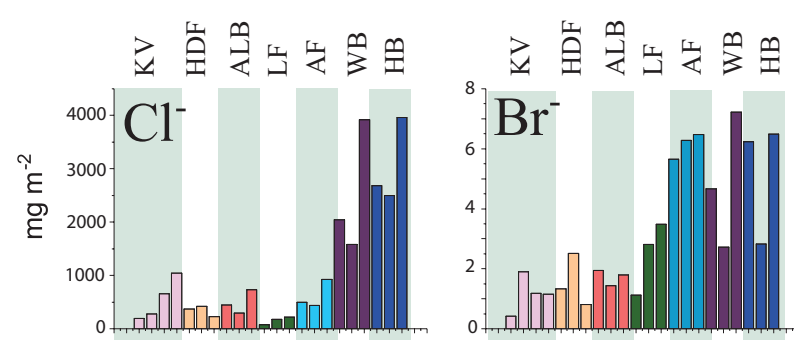

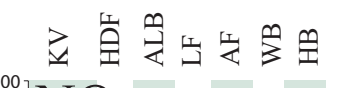
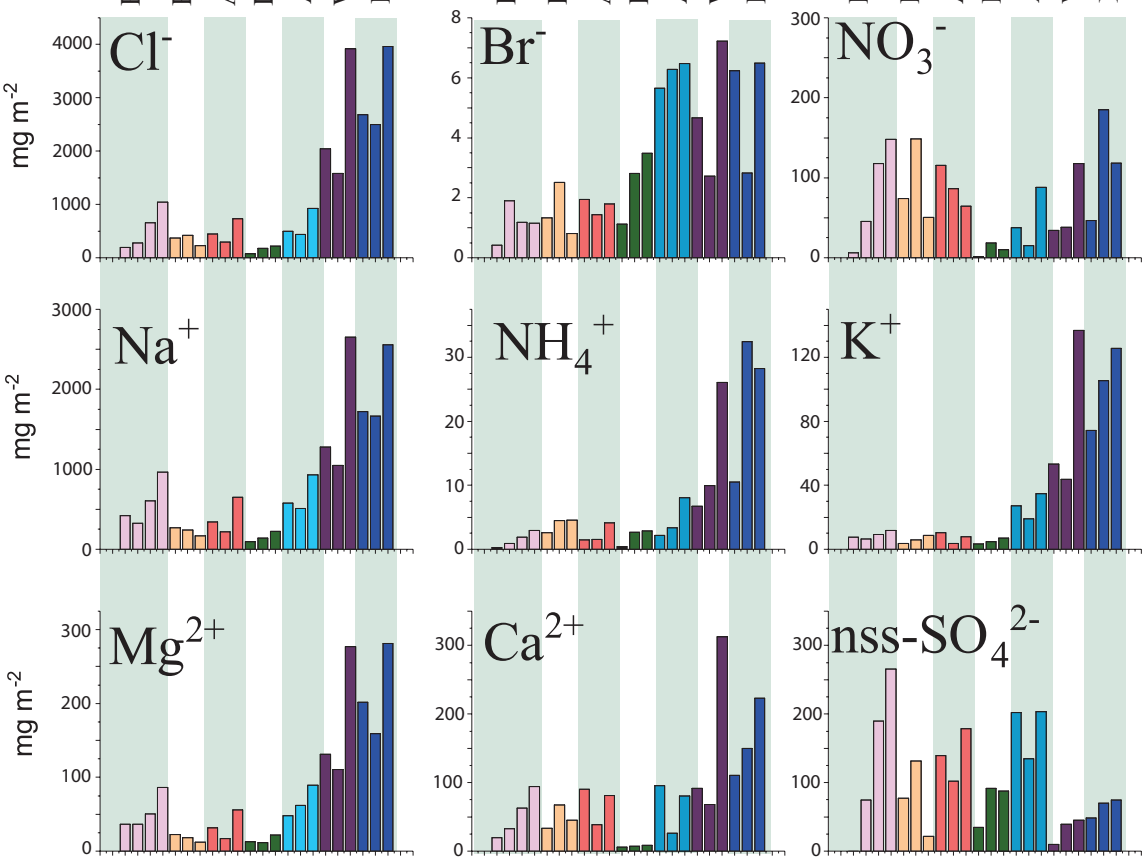
Figure 3. Panels from top: 1) $\mathrm{Cl}^{-} / \mathrm{Na}^{+}$; 2) $\mathrm{Na}^{+} / \mathrm{SO}_{4}{ }^{2-}$; 3) $\mathrm{Cl}^{-} / \mathrm{SO}_{4}{ }^{2-}$; 4) the total loads of sea-salt sulphate (ss$\mathrm{SO}_{4}{ }^{2-}$ ) and non-sea-salt sulphate (nss- $\mathrm{SO}_{4}{ }^{2-}$ ), and 5) $\mathrm{Ca}^{2+} / \mathrm{Mg}^{2+}$ - for all glaciers investigated during the $\mathrm{C} 2 \mathrm{~S} 3$ project (in the spring 2016).

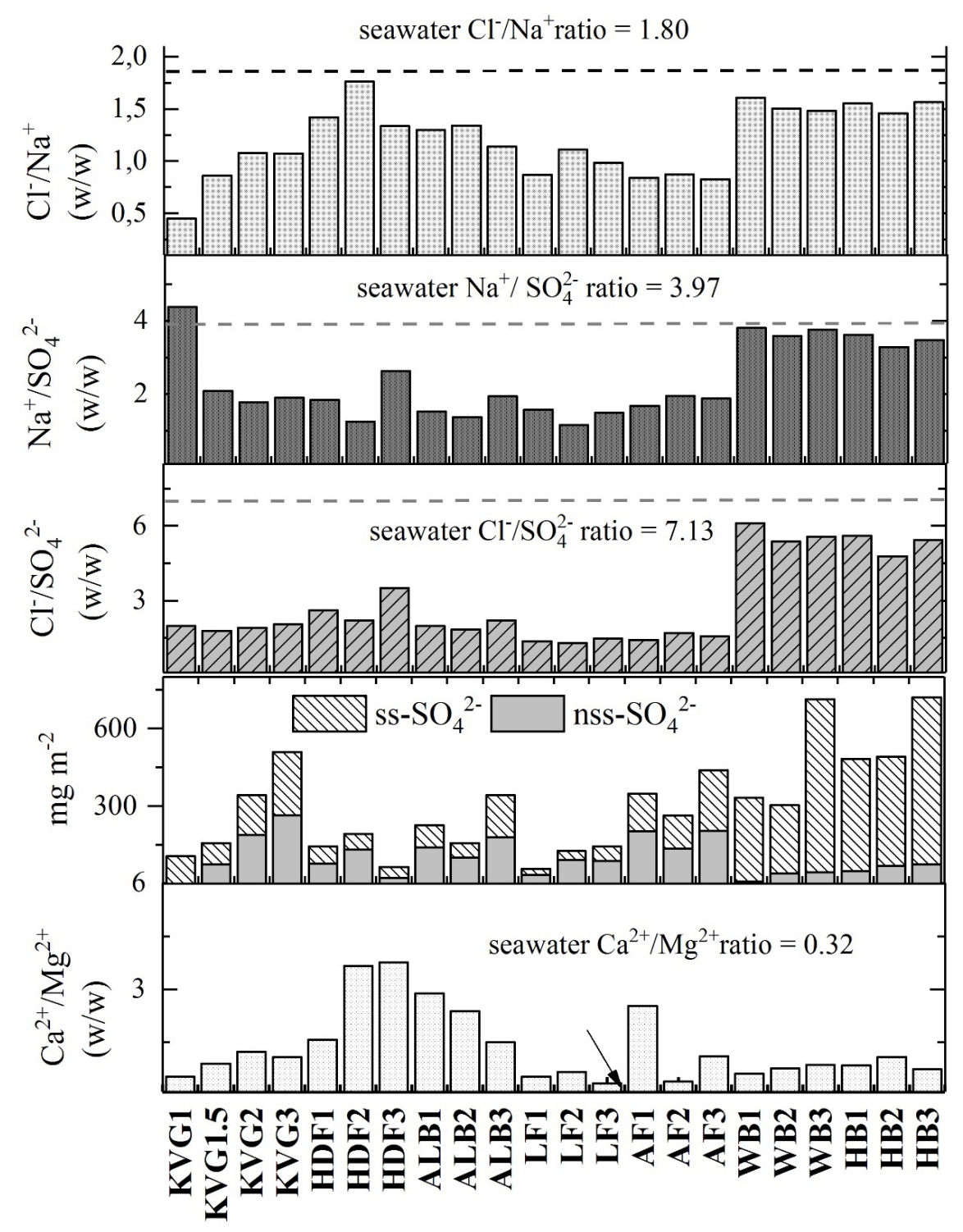


Figure 4. Sodium load in snow pits ordered by increasing elevation in $\mathrm{m}$ a.s.l., indicated by the red lines. (HB - blue; WB - purple; ALB - red; LF - green; KVG - pink; AF - light blue; HDF - orange). IQR = inter-quartile range, i.e. the difference between the value of quartiles 3 and 1 .

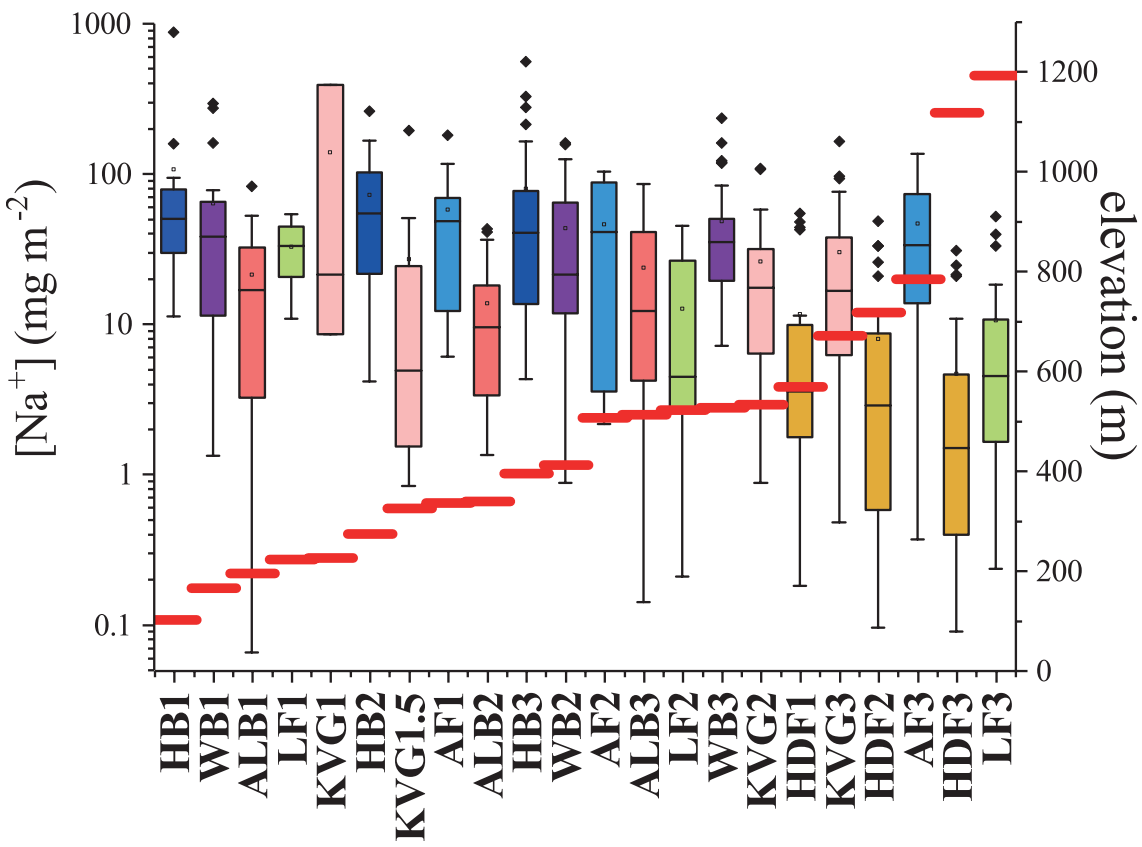


Figure 5. The correlation coefficient between oxygen isotope ratio $\left(\delta^{18} \mathrm{O}\right)$ and $\log \left[\mathrm{Na}_{\text {load }}\right]$ increases with elevation. The left axis represents the correlation coefficient $(\mathrm{R})$ between $\log \left[\mathrm{Na}_{\text {load }}\right]$ and $\delta^{18} \mathrm{O}$, using the entire dataset for each snow pit (i.e. all layers have been used for the statistical correlation). The $x$ axis indicates the altitude of the snow pit. The upper panel shows the p-value: correlations have been considered statistically significant if $\mathrm{p}<0.05$.

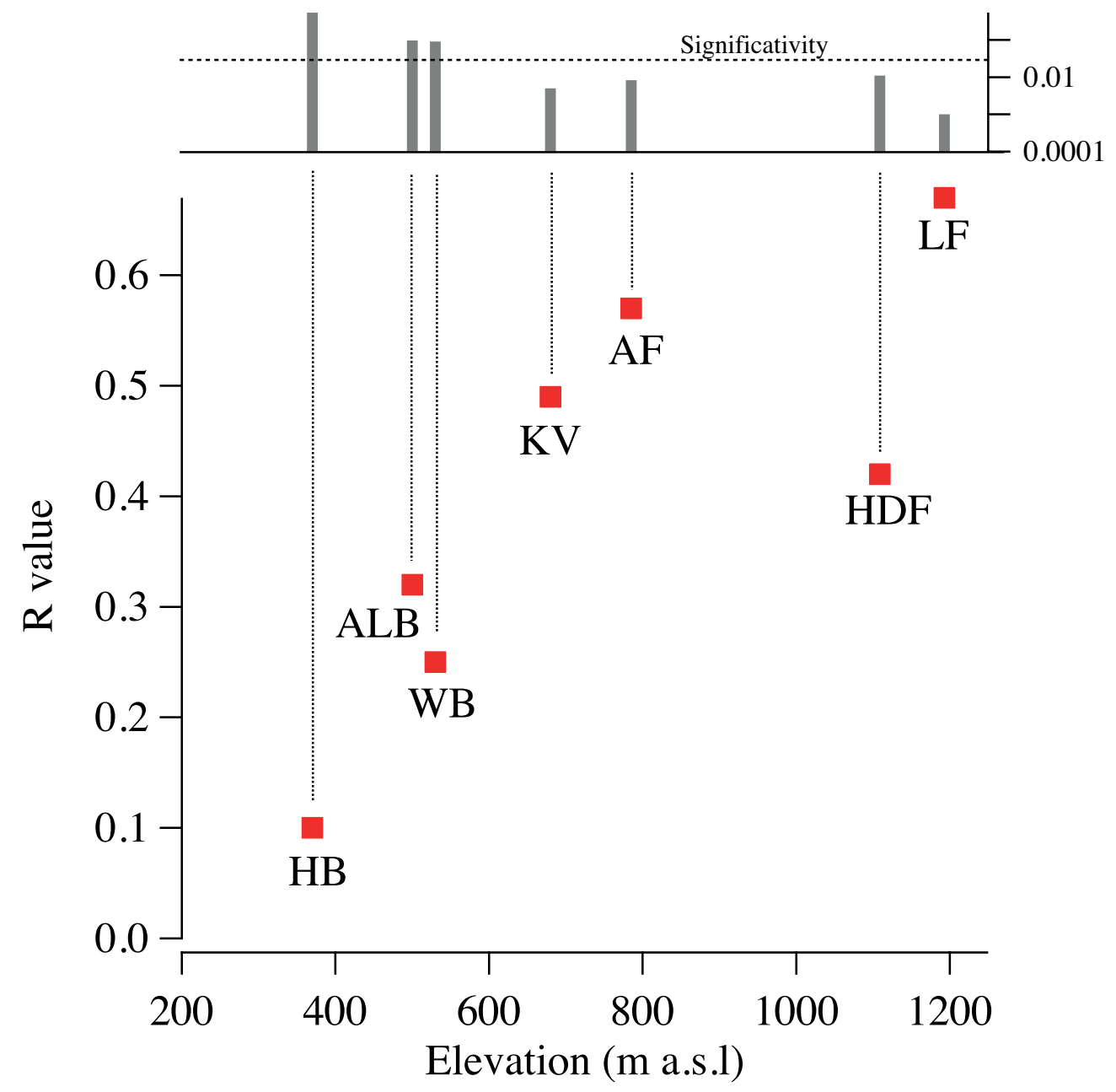




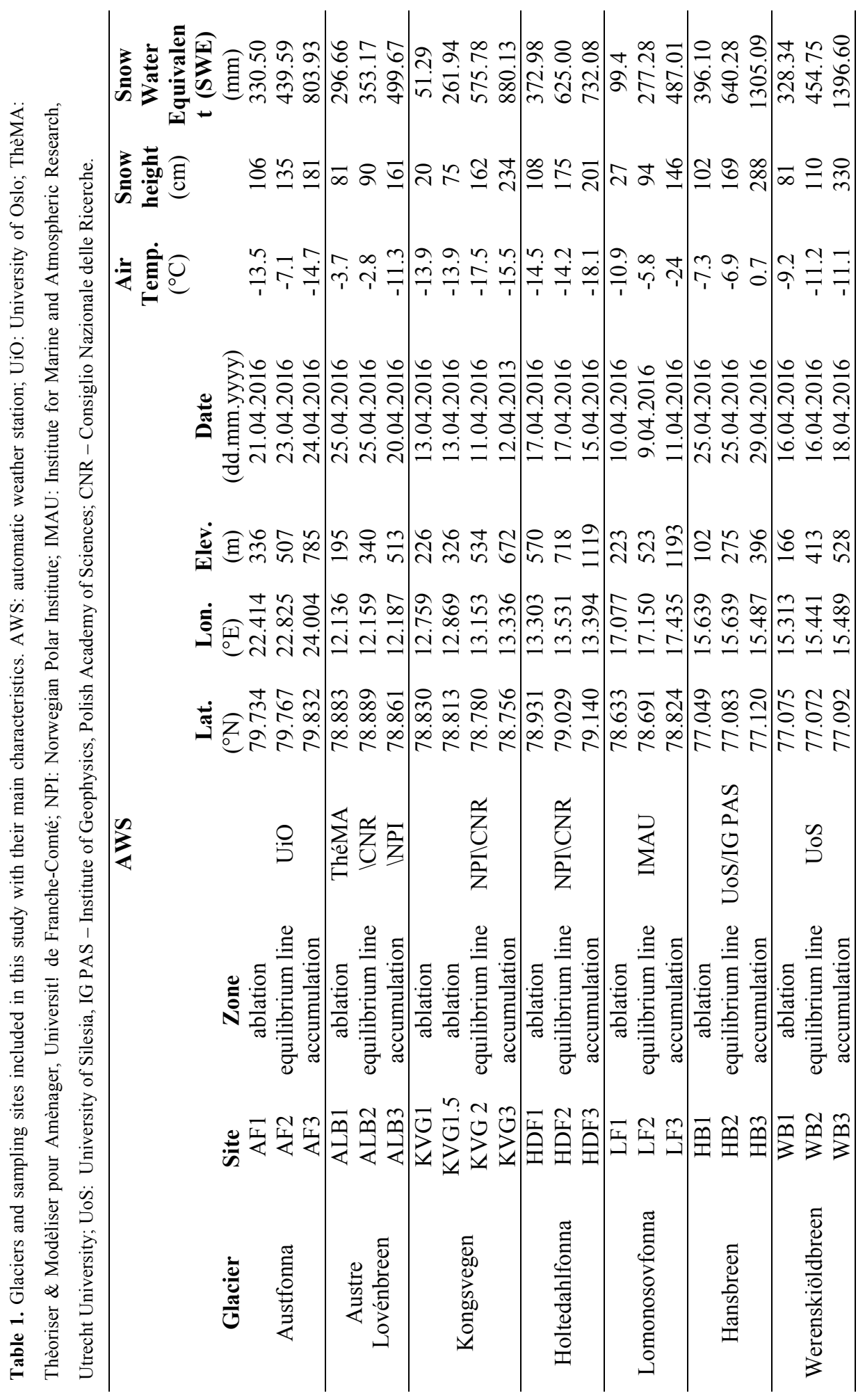




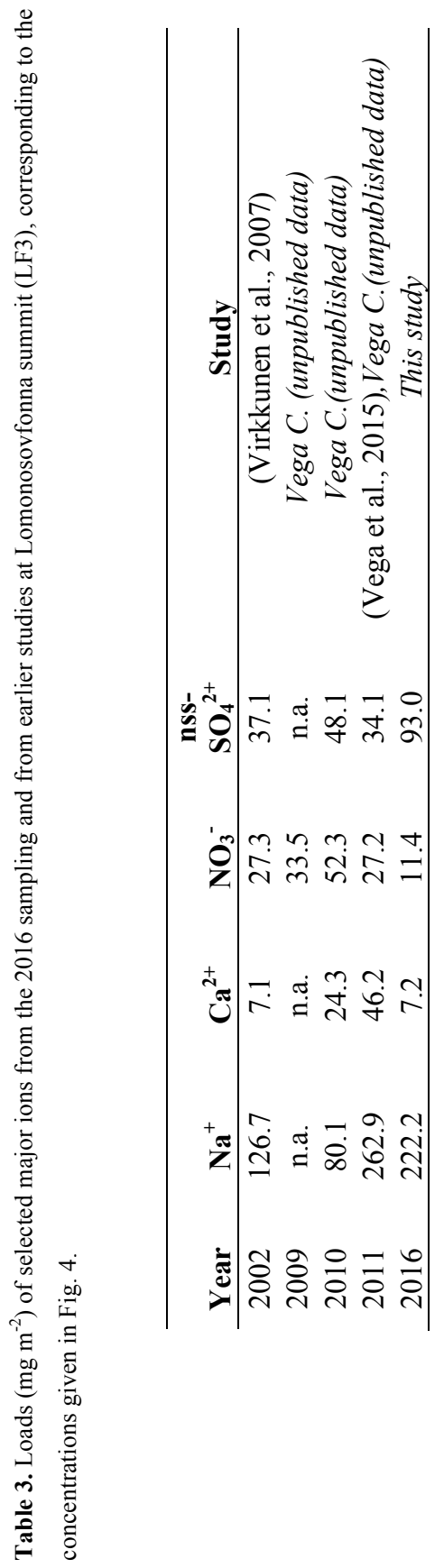




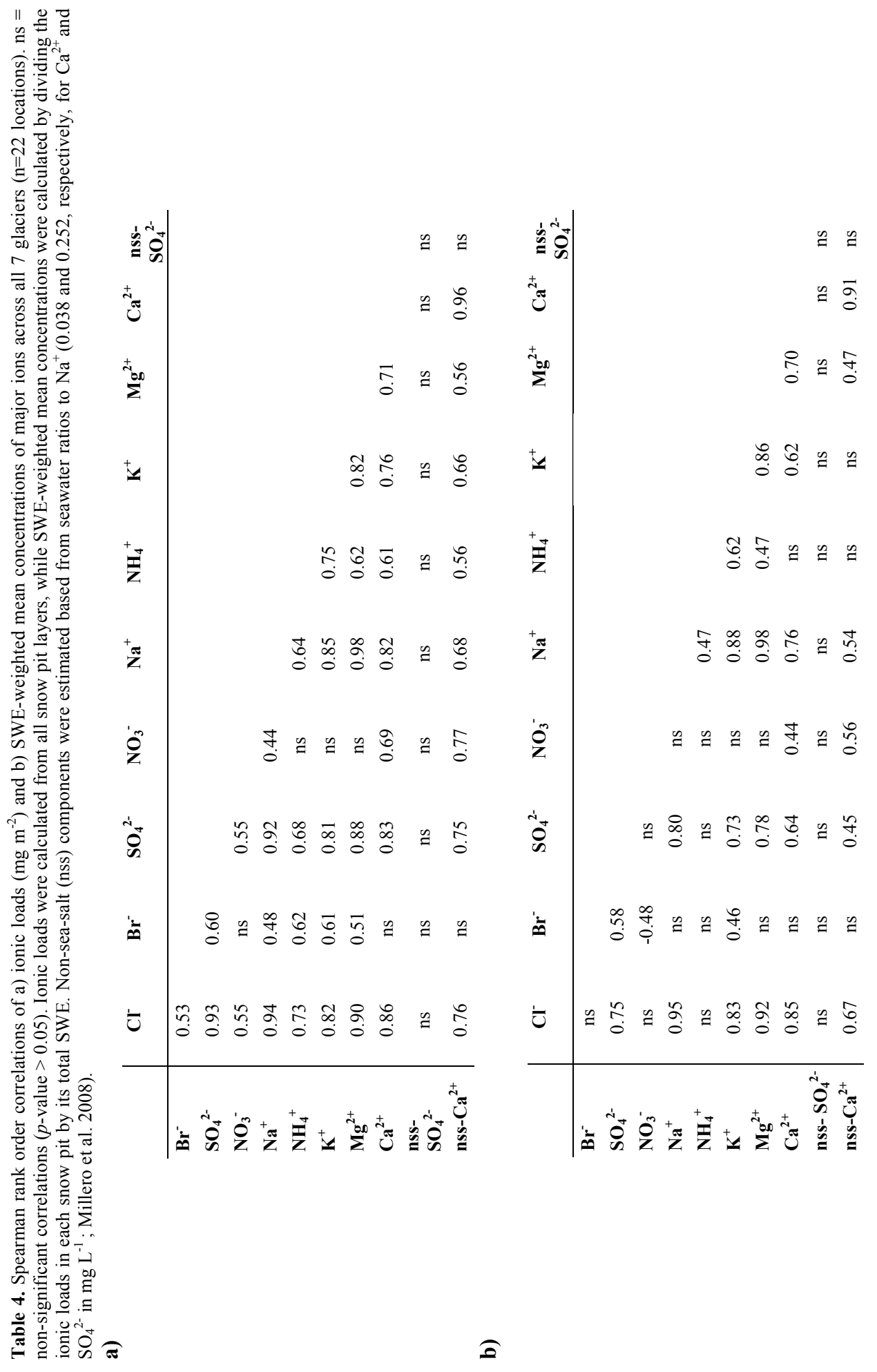

